\title{
Development of a National Fish Passage Database for Canada (CanFishPass): Rationale, Approach, Utility, and Potential Applicability to Other Regions
}

\author{
Charles Hatry, Thomas R. Binder, Caleb T. Hasler, Keith D. Clarke, Christos Katopodis, \\ Karen E. Smokorowski and Steven J. Cooke
}

\begin{abstract}
Barriers resulting from anthropogenic activities (e.g., hydropower development, irrigation, flood control, low flow augmentation) can prevent the upstream migration of fish, reducing the connectivity of river systems. As a result, great efforts have been devoted to the design and installation of engineered fishways to enable the movement of fishes across barriers. However, the literature is generally devoid of scientific papers dealing with fishway design and effectiveness, making it difficult for those developing such facilities to determine which fishway designs are most appropriate for a given system and target species. One approach for providing information to support future fishway development is through the creation of databases that contain detailed accounts of existing facilities. Described here is the development of an engineered fishway database in Canada (called CanFishPass) intended to serve as a repository for information that has previously been difficult to find. The database includes detailed geo-referenced information such as engineering details, hydraulic characteristics, and biological effectiveness of one general class of fish passage facility (i.e., engineered fishways), as well as photographs and design drawings where available. The database is searchable by species, fishway type, and ecozone, and includes a reference section comprised of both peer-reviewed and "grey" literature. It is anticipated that the database will serve as an important resource for future fishway development projects enabling quantitative analyses, while also serving as the first inventory of engineered fishways in Canada. Although our efforts to date have been focused on Canada, the expansion to a global inventory of fishways would enable opportunities to learn directly from facility operations in other regions.
\end{abstract}

Charles Hatry ${ }^{1}$, Thomas R. Binder ${ }^{1}$, Caleb T. Hasler ${ }^{1}$, Keith D. Clarke ${ }^{2}$, Christos Katopodis ${ }^{3}$,

Karen E. Smokorowski ${ }^{4}$ and Steven J. Cooke ${ }^{1}$

${ }^{1}$ Department of Biology, Carleton University, Ottawa, ON K1S 5B6

${ }^{2}$ Fisheries and Oceans Canada, Northwest Atlantic Fisheries Centre, St. John's, NL A1C 5X1

${ }^{3}$ Fisheries and Oceans Canada, Freshwater Institute, Winnipeg, MB R3T 2N6

${ }^{4}$ Fisheries and Oceans Canada, Great Lakes Laboratory for Fisheries and Aquatic Sciences, Sault Ste. Marie, ON P6A 6W4

Submitted February 2011; accepted June 2011. Written comments on this paper will be accepted until March 2012

Canadian Water Resources Journal

Revue canadienne des ressources hydriques
Vol. 36(3): 219-228 (2011) doi: $10.4296 /$ cwrj3603869
(C) 2011 Canadian Water Resources Association (c) Her Majesty in Right of Canada 
Résumé: Les obstacles qui découlent des activités anthropiques (p. ex. l'aménagement hydroélectrique, lirrigation, la lutte contre les crues, l'augmentation des basses eaux) peuvent prévenir la migration en amont du poisson, ce qui réduit la connectivité des réseaux fluviaux. Par conséquent, d'énormes efforts ont été consacrés à la conception et à l'installation de passes migratoires artificielles pour permettre la circulation des poissons entre les obstacles. Toutefois, la documentation est en général dépourvue d'articles scientifiques portant sur la conception et l'efficacité des passes à poissons, d'où la difficulté pour les concepteurs de ce genre d'ouvrages à déterminer quels sont les types de passes migratoires les plus appropriés pour un réseau donné et pour des espéces cibles. Une approche visant à fournir des données à l'appui de l'aménagement futur des passes migratoires passe par la création de bases de données qui contiennent des relevés détaillés des ouvrages existants. L'article décrit l'élaboration d'une base de données sur les passes à poissons artificielles au Canada (appelée CanFishPass), censée servir de dépôt central des sources d'information qui auparavant se sont avérées difficiles à trouver. La base de données renferme des données géoréférencées détaillées, par exemple les détails techniques, les caractéristiques hydrauliques et l'efficacité biologique d'une catégorie générale de passes à poissons (c._à-d. les passes migratoires artificielles), ainsi que des photographies et des dessins, le cas échéant. La base de données peut faire l'objet de recherches par espèce, par type de passe à poissons et par écozone. Elle englobe en outre une section de référence composée à la fois de littérature grise et de documentation évaluée par un comité de lecture. Il est prévu que la base de données constituera une importante ressource pour les futurs projets d'aménagement des passes migratoires et permettra des analyses quantitatives, tout en servant de tout premier inventaire des passes à poissons artificielles au Canada. Bien qu'à ce jour nous ayons axé nos efforts sur le Canada, l'expansion d'un inventaire global de passes à poissons favoriserait des occasions d'apprentissage direct en ce qui a trait à l'exploitation de ce type d'ouvrages dans d'autres régions.

\section{Introduction}

The disruption of normal river connectivity through the construction of barriers used for hydropower development, irrigation, flood control, and drinking water can severely damage river ecosystems, reduce the quality of fish habitat, and prevent the upstream migration of fishes (Dynesius and Nilsson, 1994; Poff et al., 1997; Acreman, 2001). Worldwide, over 45,000 dams exist (Nilsson et al., 2005) and an estimated 160-300 new barriers are constructed every year (Acreman, 2001). Barriers regulate 85 of the 113 (77\%) large rivers (discharge before human alteration of $\geq 350 \mathrm{~m}^{3} / \mathrm{s}$ ) in Canada, the United States, Europe and the former USSR (Dynesius and Nilsson, 1994).

Barriers fragment river habitats, which can have deleterious effects on riverine fish populations (Wilcox and Murphy, 1985). Isolation, as a result of damming, can lead to a loss of genetic diversity and, in some cases, can cause local extinction (Morita and Yamamoto, 2002). Barriers also have deleterious, population-level effects on diadromous (fish that migrate between fresh and salt water) and potamodromous (fish that migrate between lakes and rivers) fishes. Migratory fishes typically have different habitat requirements depending on life-stage or process (juvenile, growth, sexual maturation and reproduction) (Larinier, 2001). Migration delays, habitat loss (e.g., spawning and rearing habitat), flow alteration, temperature changes, changes in water quality and increased exposure to predators are all negative effects that barriers impose on migratory fish populations (Drinkwater and Frank, 1994; Larinier, 2001). The regulation of rivers through anthropogenic activities has led to the extinction of many populations of migratory fish on almost every continent including, Europe, Asia, Australia, North America (Larinier, 2001) and South America (Oldani et al., 2007).

In an attempt to restore river connectivity and mitigate the effects of dams on fish populations, barriers are often fitted with fishways (Clay, 1995). Fishways function as a means of passage around barriers for fish migrating both upstream and downstream (Clay, 1995). These facilities, may also partially restore habitat and river connectivity to fragmented ecosystems (Calles and Greenberg, 2009). There are documented accounts of fishways built in France approximately three hundred years ago, with the first science-based design developed in 
1909 by the Belgian scientist Denil (Clay, 1995). Further advances in design occurred in the late 1930's with the addition of engineered fishways to the Bonneville Dam on the Columbia River, USA. This project incorporated new ideas from both engineers and biologists and used increased water flows to attract fish to the fishway (Clay, 1995). In Canada, a notable fishway project occurred with the construction of the Hell's Gate vertical slot fishway in 1945, on the Fraser River, British Columbia. The fishway was installed in order to improve salmon (Oncorhynchus spp.) passage disrupted by hydraulic changes resulting from railway development. Today, numerous different types of fishways are in operation and new structures are being designed to selectively pass various target species.

In Canada, it is federally mandated by the Fisheries Act that any barrier whose impact is deemed to be of public interest by the Minister of Fisheries must be equipped with fish passage facilities, to maintain habitat connectivity and enable the free upstream and downstream passage of fishes (Fisheries Act, F-14 s.20, 2010). While the engineering aspects of fishway design have been previously explored (see bibliography of Katopodis, 1992; Clay, 1995; Thorncraft and Harris, 1996; Katopodis et al., 1997; Ead et al., 2004; Khan, 2006; Rodriguez et al., 2006), the literature is generally short of scientific papers addressing the effectiveness of different designs for passing fishes. Indeed, a global review of peerreviewed published articles on fish-passage facility effectiveness yielded only 96 papers (Roscoe and Hinch, 2010). The lack of information regarding the effectiveness of various fishway designs, in ensuring ease of target species passage, makes it difficult for those embarking on fishway development projects to determine which designs are best suited for a given system. To highlight this point, a study performed in 1997 with the purpose to assess the efficacy of a Denil fishway designed to pass walleye (Sander vitreus) found that none of the 24 radio tagged walleye successfully moved through the fishway (Bunt et al., 2000). Researchers determined that walleye were not able navigate around corners of the fishway. Other fishways that have been designed with general specifications or with target species in mind may be equally ineffective in passing some fish species. As a result, there is a need for a repository where information can be made readily available to support future fishway projects. One way of making the information accessible is through the development of a database that contains detailed accounts of fishway facilities.

\section{Approach: Development of a Canadian Fish Passage Database}

To address the need for a national repository for fishway-related information, we have created the Canadian Fish Passage (CanFishPass) Database. The database is not static and was designed to be continually updated with new information. This national database contains detailed geo-referenced information on engineering and hydraulic specifications, and the biological effectiveness of engineered fishways in order to support future projects in Canada.

Information for CanFishPass was first compiled from an extensive literature search using the following web-based resources: Google Scholar, Fisheries and Oceans Canada (DFO) websites, the WAVES database (DFO online library), American Fisheries Society libraries, Web of Science, Scopus, Science Direct, hydropower company websites and finally through normal Google web searches. Searches were performed without a specifically defined set of search terms, search terms were employed at the discretion of the researcher in a fashion designed to maximize the information returned by the search. Google Scholar yielded the highest number of peer reviewed articles, while normal Google searches yielded the most grey literature information. Web-based searching identified 104 fishways in Canada. However, information gathered from internet sources other than peerreviewed articles consisted mainly of the name of the fishway only, with information such as location and species known to use the fishway frequently missing which may partly reflect that the data do not exist. After conducting web based searches, a request letter for further information and help in identifying additional Canadian fishways was sent out in the form of an e-mail to individuals that might have information on fishways in their region. The e-mail was distributed to DFO employees (science and habitat branch), provincial resource management agencies nationwide, environmental consultants, hydropower utilities (directly and via the Canadian Electricity Association), and other government agencies (e.g., Environment Canada, Parks Canada). Recipients were encouraged to forward the e-mail to anyone 
they thought might be able to provide information on fishways in their area. The request for information identified an additional 40 fishways, bringing the total to 139 . As of September $20^{\text {th }}, 2011$, the database has reached 201 fishways and will continue to grow as new information is forwarded to us as the database is publicized. Anyone with knowledge of a fishway in Canada may contribute to the database (after verification by CanFishPass personnel) by providing information to CanFishPass.

\section{Database Details}

CanFishPass is a relational database consisting of three separate tables, a Canadian references table, a fishway table, and a fish table (Figure 1). The database is designed in Microsoft Access to serve as a data repository for fishway information. Primary keys for the tables are reference ID for the Canadian references table, name of dam/barrier for the fishway table, and fish ID for the fish table.

The Canadian references table contains accounts from the primary and grey literature, as well as personal communications, of a fish species' use of a particular fishway. There are 18 available data fields for each reference (Table 1). Information in the Canadian references table includes the type of reference (peer reviewed, grey literature, etc.), fish species, information on species-specific passage efficiency of the fishway, and the reference source. A separate record is generated for every documented instance of a species' use of a fishway.

Location, engineering and technical specifications, and evaluation information for each known fishway are stored in the Fishway Table. There are 36 fields available for input for each fishway (Table 2) Information for separate fields may be entered as it is discovered. Fishway designs were identified as: vertical slot, Denil, Ice Harbour, pool and weir, trap

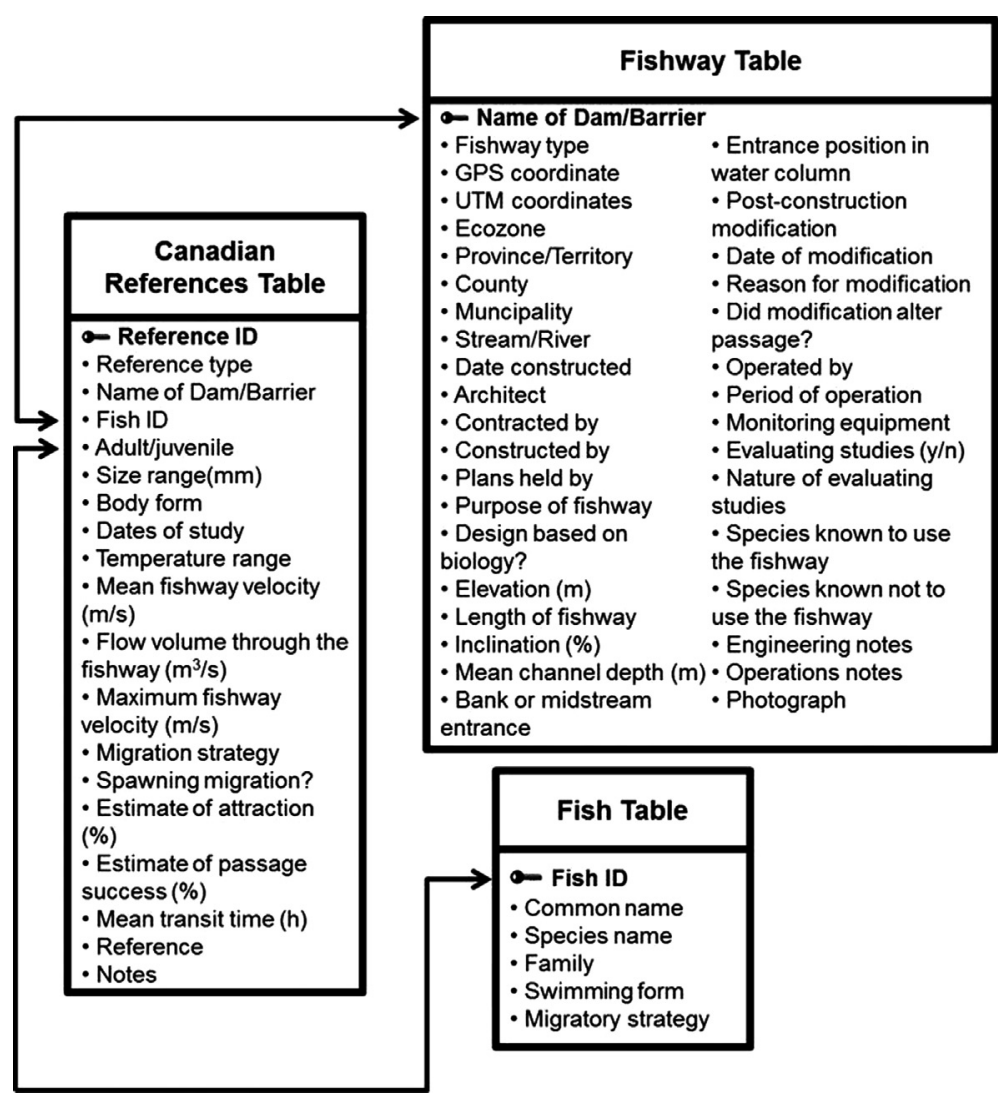

Figure 1. Conceptual design of the Canadian Fish Passage (CanFishPass) Inventory Project. The final product will be a website on which users may construct and print/export customized reports based on searchable fields within 3 separate databases. 
Table 1. Fields for the Canadian References Table and Form.

\begin{tabular}{|c|c|c|c|}
\hline Property & Fields & Data Type & Description \\
\hline \multirow[t]{5}{*}{ Identity } & Reference ID & AutoNumber & Unique ID number \\
\hline & Reference type & Text - Value list & $\begin{array}{l}\text { Peer reviewed research article, government/ } \\
\text { industry report, personal communication, other }\end{array}$ \\
\hline & Fish ID & Number & $\begin{array}{l}\text { Unique ID number for searching and linking } \\
\text { with Fish Table }\end{array}$ \\
\hline & Name of dam/ & Lookup from the & Dam/barrier name, links Canadian Reference \\
\hline & barrier & $\begin{array}{l}\text { Fishway Table using } \\
\text { dam/barrier name }\end{array}$ & Table with the Fishway Table \\
\hline \multirow[t]{17}{*}{ Fish info* } & Scientific name & Lookup from Fish & e.g., Onchorhynchus mykiss \\
\hline & & Table using Fish ID & \\
\hline & Common name & Lookup from Fish & e.g., rainbow trout \\
\hline & & Table using Fish ID & \\
\hline & Adult/juvenile & Text - Value list & Adult, juvenile or both \\
\hline & Size range & Text & Range in size of individuals that use the fishway \\
\hline & Dates of use & Text & Dates fishway is used by species \\
\hline & $\begin{array}{l}\text { Temperature } \\
\text { range }\end{array}$ & Text & $\begin{array}{l}\text { Temperature range over which the fish use the } \\
\text { fishway }\end{array}$ \\
\hline & Spawning & Text- Value list & Yes or no \\
\hline & migration? & & \\
\hline & $\begin{array}{l}\text { Mean fishway } \\
\text { velocity }(\mathrm{m} / \mathrm{s})\end{array}$ & Number & $\begin{array}{l}\text { Average velocity of water flow through the } \\
\text { fishway }\end{array}$ \\
\hline & $\begin{array}{l}\text { Maximum } \\
\text { fishway velocity } \\
(\mathrm{m} / \mathrm{s})\end{array}$ & Number & $\begin{array}{l}\text { Maximum velocity of water flow recorded in } \\
\text { the fishway }\end{array}$ \\
\hline & $\begin{array}{l}\text { Estimate of } \\
\text { attraction }\end{array}$ & Number & $\begin{array}{l}\text { Portion of individuals attracted to the fishway } \\
\text { (\%) }\end{array}$ \\
\hline & $\begin{array}{l}\text { Estimate of } \\
\text { passage success }\end{array}$ & Number & $\begin{array}{l}\text { Portion of individuals that successfully transit } \\
\text { the fishway (\%) }\end{array}$ \\
\hline & Mean transit time & Number & Mean time it takes fish to transit the fishway (h) \\
\hline & Reference & Memo & $\begin{array}{l}\text { e.g., Smith et al, } 2009 \text { Journal of Fish Biology, } \\
\text { 45: } 124-131 \text { or John Smith, personal } \\
\text { communication, April 12, } 2009\end{array}$ \\
\hline & Notes & Memo & Notes pertaining to species' use of fishway \\
\hline
\end{tabular}

*Each incidence of fish use in a given reference will be given its own record.

and sort, lamprey ramp, pool and orifice, pool and riffle, and rock ramp. A fishway type of 'other' was assigned to fishways that did not fall into any of the main categories but were still considered to facilitate upstream migration (e.g., rock blasted fish stairs at Nib's Falls, Puntledge River, British Columbia). Culvert fishways, for example culverts with baffles inside, were not included in the fishway database as they are extremely numerous and because the primary focus for the project is on hydropower dams. A description of how the fishway operates is listed in the 'operation notes' text box. Ecozones were designated using the Environment Canada (2009) terminology and maps. Ideally, photographs or pictures of every dam or barrier equipped with a fishway will be available for viewing by the user. Photographs could range from pictures of the fishway to more in-depth engineering schematics showing design specifications. 
Table 2. Fields for the Fishway Table and Form

\begin{tabular}{|c|c|c|c|}
\hline Property & Fields & Data Type & Description \\
\hline \multirow[t]{2}{*}{ Identity } & Name of dam/barrier & Text & Dam/barrier name \\
\hline & Fishway type & Text - Value list & $\begin{array}{l}\text { Vertical slot, Denil, Ice Harbour, pool and weir, } \\
\text { trap and sort, eel ladder, lamprey ramp, pool and } \\
\text { orifice, pool and riffle, rock ramp, other, unknown }\end{array}$ \\
\hline \multirow[t]{9}{*}{ Location } & GPS coordinates & Text & Latitude and longitude \\
\hline & GPS latitude & Number & In decimal format \\
\hline & GPS longtitude & Number & In decimal format \\
\hline & UTM coordinates & Text & Universal Transverse Mercator coordinates \\
\hline & Province/Territory & Text - Value list & Province that the fishway is found in \\
\hline & Ecozone & Text - Value list & $\begin{array}{l}\text { Ecozones are defined by the Environment } \\
\text { Canada ecozones map }\end{array}$ \\
\hline & $\begin{array}{l}\text { County or Regional } \\
\text { District }\end{array}$ & Text & County or Regional District \\
\hline & Municipality & Text & Closest city or township \\
\hline & Stream/River & Text & Water body in which the fishway resides \\
\hline \multirow[t]{8}{*}{ Engineering } & Date built & Text & When was the fishway built? \\
\hline & Engineer & Text & Who designed the fishway? \\
\hline & Contracted by & Text & What agency contracted the fishway? \\
\hline & Constructed by & Text & What company constructed the fishway? \\
\hline & Plans held by & Text & $\begin{array}{l}\text { Who would an agency need to contact to obtain } \\
\text { plans? }\end{array}$ \\
\hline & Type of fishway & Text & e.g., Denil, vertical slot \\
\hline & Purpose of fishway & Text & What species was the fishway designed to pass? \\
\hline & $\begin{array}{l}\text { Designed based on } \\
\text { biology? }\end{array}$ & Text - Value list & $\begin{array}{l}\text { Was the fishway design based on the biology of } \\
\text { the species? Yes/no }\end{array}$ \\
\hline \multirow[t]{6}{*}{$\begin{array}{l}\text { Design } \\
\text { specifications }\end{array}$} & $\begin{array}{l}\text { Bank or midstream } \\
\text { entrance }\end{array}$ & Text - Value list & Bank/midstream \\
\hline & $\begin{array}{l}\text { Entrance position in } \\
\text { water column }\end{array}$ & Text - Value list & Bottom, mid-column or surface \\
\hline & Elevation & Number & $\begin{array}{l}\text { Height difference between fishway exit and } \\
\text { entrance }(\mathrm{m})\end{array}$ \\
\hline & Length of fishway & Number & Length of fishway $(\mathrm{m})$ \\
\hline & Inclination & Number & Angle of inclination (\%) \\
\hline & Mean channel depth & Number & Mean channel depth during fishway operations (m) \\
\hline \multirow[t]{11}{*}{ Operations } & Operated by & Text & Agency responsible for operations \\
\hline & Period of operation & Text & Dates of operation \\
\hline & Monitoring equipment & Text & $\begin{array}{l}\text { Any monitoring equipment (e.g., video counting, } \\
\text { PIT-tag antennas) }\end{array}$ \\
\hline & Evaluating studies? & Text - Value list & Have evaluation studies been performed? \\
\hline & $\begin{array}{l}\text { Nature of evaluation } \\
\text { studies }\end{array}$ & Memo & e.g., Survey of fish use, passage efficiency \\
\hline & $\begin{array}{l}\text { Post construction } \\
\text { modifications? }\end{array}$ & Text - Value list & Yes/no \\
\hline & Date of modification & Text & Month/year \\
\hline & Reason for modification & Text & \\
\hline & $\begin{array}{l}\text { Did modification alter } \\
\text { passage? }\end{array}$ & Text - Value list & Increase/decrease/no effect/unknown \\
\hline & $\begin{array}{l}\text { Species known to use } \\
\text { fishway }\end{array}$ & Memo & List all species known to use the fishway \\
\hline & $\begin{array}{l}\text { Species known not to } \\
\text { use the fishway }\end{array}$ & Memo & $\begin{array}{l}\text { Species for which it is known that the fishway } \\
\text { presents a significant barrier to migration }\end{array}$ \\
\hline \multirow[t]{3}{*}{ Notes } & Engineering notes & Memo & Notes regarding design and construction \\
\hline & Operations notes & Memo & Notes regarding operations \\
\hline & Photographs & OLE object & Photographs of the fishway \\
\hline
\end{tabular}


In Table 1, Fish ID refers to a unique value (numerical) given to each species found in Canada. Species common in Canada were identified using Scott and Crossman's Freshwater Fishes of Canada (1973) and were compiled in a 'fish table'. By relating the fish table to the Canadian reference table and fishway table, reports will be generated from multi-level queries and can include desired information from all three tables (Table 3). Additional species (such as introduced species) will be added as necessary.

\section{Utility}

CanFishPass will soon be accessible on the internet where it may be a useful reference for hydraulic engineers, fisheries managers, regulators, utilities, and fish researchers. Currently the website for the database is under construction so those with an interest in learning more about the project are encouraged to visit http://www.carleton.ca/fecpl/canfishpass.html to request a report or a copy of the database. As data holdings accumulate, the website may serve as a critical resource for determining the utility of fishways in Canada. It will also be available as a resource for the construction of new fishways, and can be used by researchers to identify potential research sites for biological and hydraulic investigations. More importantly the database can be used to determine the type of fishway that has been most successful in passing target species.

Customized reports will be created by searching the database for desired information. For example, a customized search on use of fishways by coho salmon (Oncorbynchus kisutch) in Canada produced the results shown in Table 3. Fields searched were Fish ID, common name, species name, province or territory, the fishway type, the name of the dam or barrier, the stream or river where the fishway is found, and the references documenting the species use of the fishway. Records contributed to CanFishPass may help determine the factors that facilitate successful passage by fish through barriers with negligible delay or biological consequence as a common requirement of industry in meeting Fisheries Act regulations.

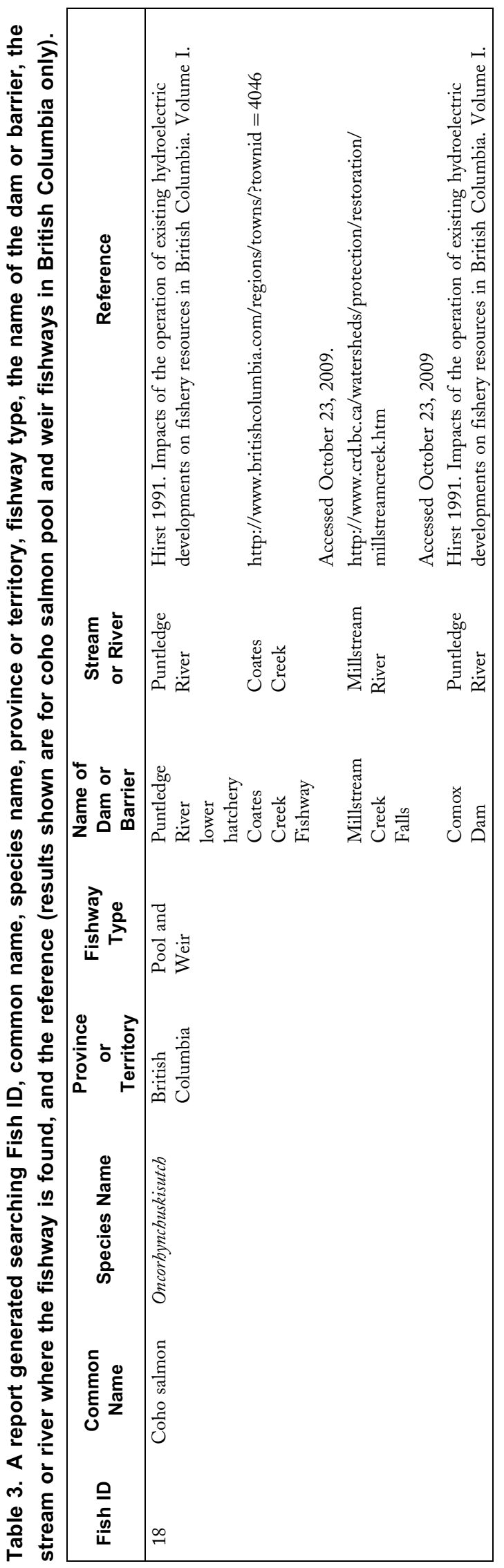




\section{Potential Applicability to Other Regions}

Barriers severely compromise both potamodromous and diadromous fish populations by fragmenting habitat and preventing migration along streams and rivers. As a result, fishways have been constructed to bypass barriers on many continents, but little research has been performed to test the efficiency of different fishway designs (Roscoe and Hinch, 2010). As far as we are aware, CanFishPass is a unique repository of fishway information. The addition of an International References Table is planned for the future, which may enable CanFishPass to serve as a global repository of fishway information. Through the addition of international references, Canadian researchers and fish passage facility designers will have easy access to information on fish passage projects conducted around the world, learning from past projects and improving future projects in Canada. International researchers will be able to examine information on the design and operation of fishways in Canada. International collaboration to improve the design and operation of fishways could help mitigate many of the negative effects imposed on fish populations by barriers, resulting in healthier coastal, river, and terrestrial ecosystems. Our hope is that this paper will generate interest in CanFishPass as well as provide a template for development of similar databases in other jurisdictions.

\section{Acknowledgements}

Financial assistance was provided by the Fish Ecology and Conservation Physiology Laboratory at Carleton University and Fisheries and Oceans Canada's Center of Expertise on Hydropower Impacts on Fish and Fish Habitat. Cooke is supported by the Canada Research Chairs program. Cooke, Smokorowski, Clarke and Katopodis are members of the Natural Sciences and Engineering Research Council of Canada HydroNet Strategic Network. The comments from anonymous referees improved this manuscript.

\section{References}

Acreman, M.C. 2001. Hydro-ecology: linking hydrology and aquatic ecology. The International Association of Hydrological Sciences, United Kingdom. 1-18 pp.

Bunt, C.M., S.J. Cooke, and R.S. McKinley. 2000. Assessment of the Dunnville Fishway for passage of walleyes from Lake Erie to the Grand River, Ontario. Journal of Great Lakes Research 26: 482488.

Calles, O., and L. Greenberg. 2009. Connectivity is a two-way street - the need for a holistic approach to fish passage problems in regulated rivers. River Research and Applications 25: 1268-1286.

Clay, C.H. 1995. Design of fishways and other fish facilities, 2nd edition. Lewis Publishers, Boca Raton, USA. 301 pp.

Drinkwater, K.F., and K.T. Frank. 1994. Effects of river regulation and diversion on marine fish and invertebrates. Aquatic Conservation: Freshwater and Marine Ecosystems 4: 135-151.

Dynesius, M., and C. Nilsson. 1994. Fragmentation and flow regulation of river systems in the northern third of the world. Science 266: 753-762.

Ead, S.A., C. Katopodis, G.J. Sikora, and N. Rajaratnam. 2004. Flow regimes and structure in pool and weir fishways. Journal of Environmental Engineering Science 3: 379-390.

Environment Canada. Canadian ecosystems. http:// www.ec.gc.ca/subsnouvelles-newsubs/0C1F54C76D14-9CE1-44D3-6F01FE67498B/f2-en.gif (Accessed, April 2009).

Fisheries Act. 2010. R.S., 1985, c. F-14, s. 20. Department of Justice Canada. 
Katopodis, C. 1992. Introduction to fishway design. Freshwater Institute, Central and Arctic Region, Department of Fisheries and Oceans Canada. 70 pp.

Katopodis, C., N. Rajaratnam, S. Wu, and D. Tovell. 1997. Denil fishways of varying geometry. Journal of Hydraulic Engineering 123: 624-631.

Khan, L.A. 2006. A three-dimensional computational fluid dynamics (CFD) model analysis of free surface hydrodynamics and fish passage energetics in a vertical-slot fishway. North American Journal of Fisheries Management 26: 255-267.

Larinier, M. 2001. Environmental issues, dams and fish migration. Dams, fish and fisheries: Opportunities, challenges and conflict resolution. FAO Fisheries Technical Paper 419: 45-90.

Morita, K., and S. Yamamoto. 2002. Effects of habitat fragmentation by damming on the persistence of stream-dwelling charr populations. Conservation Biology 16: 1318-1323.

Nilsson, C., C.A. Reidy, M. Dynesius, and C. Revenga. 2005. Fragmentation and flow regulation of the world's large river systems. Science 308: 405-408.

Oldani, N.O., C.R.M. Baigun, J.M. Nestler, and R.A. Goodwin. 2007. Is fish passage technology saving fish resources in the lower La Plata River basin? Neotropical Ichthyology 5: 89-102.

Poff, L.N., J.D. Allan, M.B. Bain, J.R. Karr, K.L. Prestegaard, B.D. Richter, R.E. Sparks, and J.C. Stromberg. 1997. The natural flow regime: A paradigm for river conservation and restoration. BioScience 47: 769-784.

Rodriguez, T.T., J.P. Agudo, L.P. Mosquera, and E.P. Gonzalez. 2006. Evaluating vertical-slot fishway designs in terms of fish swimming capabilities. Ecological Engineering 27: 37-48.
Roscoe, D.W., and S.G. Hinch. 2010. Effectiveness monitoring of fish passage facilities: historical trends, geographic patterns and future directions. Fish and Fisheries 11: 12-33.

Scott W.B. and E.J. Crossman. 1973. Freshwater fishes of Canada. Environment Canada, Fisheries and Oceans Canada, Canada. 966 pp.

Thorncraft G.A. and J.H. Harris. 1996. Assessment of rock-ramp fishways. A report for the NSW Fisheries Research Institute and the Cooperative Research Centre for Freshwater Ecology, Australia. 41 pp.

Wilcox, B.A., and D. Murphy. 1985. Conservation strategy: the effect of fragmentation on extinction. The American Naturalist 125: 879-887. 


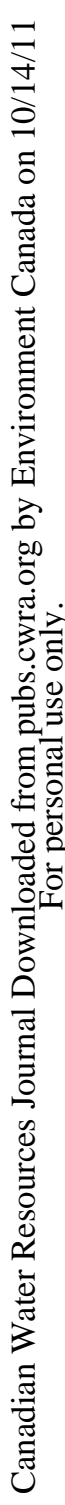

$\overline{0}$

윰노

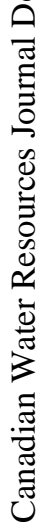

